\title{
FORMULASI / MODEL SISTEM PEMIDANAAN ANAK DI INDONESIA
}

\author{
Ahmad Syakirin \\ Institut Agama Islam Negeri Ponorogo \\ ahmadsyakirinstarfruit@yahoo.co.id
}

\begin{abstract}
Criminal systems that are restorative Justice must be the priority of the judge in making decisions. Placing a child in prison is always the last choice and with the shortest possible period of time. Placing children in institutions that have social benefits and functions as well as improvements for children, Children have the potential for growth in the future, so that children should be given guidance, care, education, and protection, as well as skills, both physically, mentally, and socially . Therefore a child who commits a crime is required by a child-only court. The child punishment system must pay attention to the interests of the child and in accordance with the standards of value and treatment of a number of national and international instruments. Diversion and the concept of Restorative justice need to be taken into consideration in handling child cases. This concept involves all parties in order to improve children's morale so that they do not repeat their actions anymore, and children do not feel like a prisoner that affects the child's mental development.
\end{abstract}

Keywords: System, Criminalization, Child Criminal

\begin{abstract}
ABSTRAK
Sistem pemidanaan yang bersifat Restoratif Justice harus menjadi prioritas hakim dalam menjatuhkan putusan. Menempatkan anak pada penjara senantiasa menjadi pilihan terakhir dan dengan jangka waktu yang sesingkat mungkin. Menempatkan anak pada lembaga-lembaga yang mempunyai manfaat dan fungsi sosial serta perbaikan bagi anak, Anak memiliki potensi tumbuh kembang di masa depan, sehingga anak patut diberikan pembinaan, perawatan, pendidikan, dan perlindungan, serta keterampilan, baik secara fisik, mental, dan sosial. Oleh karena itu anak yang melakukan tindak pidana diperlukan pengadilan khusus anak. Sistem pemidanaan anak harus memperhatikan kepentingan anak dan sesuai dengan standar nilai dan perlakuan sejumlah instrumen nasional maupun internasional. Diversi dan konsep Restorative justice perlu menjadi bahan pertimbangan dalam penanganan kasus anak. Konsep ini melibatkan semua pihak dalam rangka untuk perbaikan moral anak agar tidak lagi mengulangi perbuatannya, dan anak tidak merasa menjadi seperti seorang pesakitan sehingga mempengaruhi perkembangan mental anak.
\end{abstract}

Kata Kunci : Sistem, Pemidanaan, Pidana Anak

\section{PENDAHULUAN}

Pembahasan mengenai hukum erat kaitannya dengan berbicara tentang ide dasar double track system, bermakna berbicara tentang gagasan dasar mengenai sistem sanksi yang menjadi dasar kebijakan dan penggunaan sanksi dalam hukum pidana. Dalam hal ini, sistem pemidanaan kita mengenal sistem dua jalur dalam 
hukum pidana, yakni sanksi pidana dan sanksi tindakan atau yang lebih kita kenal double track System bukan satu jalur, yaitu single track sistem yaitu model pidana saja. $^{1}$

Dari perdebatan oleh para ahli hukum pidana terungkap dengan jelas bahwa sekalipun jenis sanksi pidana yang bersumber dari teori retributif memiliki kelemahan dari segi proporsionalitas atau tanggung jawab si pelaku kejahatan terhadap perbuatannya, namun retributivisme tidak mungkin dihilangkan sama sekali meskipun terlebih khusus mengenai anak yang bermasalah dengan hukum. Justru kaum retributivisme telah menyumbangkan pemikiran tentang pemidanaan dari perspektif filsafat yang menghargai manusia sebagai individu yang matang dan bertanggung jawab atas segala prilaku dan tindakannya. Tingkat kematangan dan tanggung jawab tersebut menentukan berat ringannya pemidanaan.

Demikian pula dengan adanya pusat rehabilitas dan prevensi sebagai tujuan utama dari jenis sanksi tindakan/treatment/ide diversi anak. Meski cara ini memilki keistimewaan dari segi proses resosialisasi pelaku, sehingga diharapkan mampu memulihkan kualitas sosial dan moral seseorang/anak agar dapat berintegrasi lagi dalam masyarakat.

Kesetaraan kedudukan antara sanksi pidana dan sanksi tindakan sangat bermanfaat untuk memaksimalkan penggunaan kedua jenis sanksi tersebut secara tepat dan proporsional. Sebab, kebijakan sanksi yang integral dan seimbang antara sanksi pidana dan sanksi tindakan (restortrif justice dengan bentuk diversi, dengan cara memaksimalkan penyelesaian melalui mediasi penal). Selain menghindari penerapan sanksi yang fragmentaristik (yang selalu menekankan pada sanksi pidana) juga menjamin keterpaduan sistem sanksi yang bersifat individual dan sistem sanksi yang bersifat fungsional. Sanksi pidana lebih menekankan pada unsur pembalasan (pengimbalan/setimpal). Wajar saja, hal ini merupakan penderitaan yang sengaja dibebankan kepada seorang pelanggar. Sedangkan sanksi tindakan yang bersumber dari ide dasar perlindungan masyarakat, ide harmonisasi, mengutamakan ide kekhususan pada anak.

\footnotetext{
${ }^{1}$ Sholahuddin, Sistem sanksi Dalam Hukum Pidana (Ide Dasar Double Track Sistem dan Implementasinya), Rajawali Pers, Jakarta, 2004, h. 24.
} 
Adanya berbagai perlakuan khusus ini, maka anak yang berkonflik dengan hukum yang selanjutnya disebut anak adalah anak yang telah berumur 12 (dua belas) tahun, tetapi belum berumur 18 (delapan belas) tahun yang diduga melakukan tindak pidana anak yang tidak boleh diproses hukum hanya anak di bawah 12 tahun, sementara anak dibawah usia 14 tahun atau di atas 12 tahun boleh diproses, sedangkan usia 14 tahun ke atas atau kurang dari 18 tahun boleh ditahan. Substansi yang paling mendasar dalam Undang-Undang ini adalah pengaturan secara tegas mengenai Keadilan Restoratif melalui proses diversi yang dimaksudkan untuk menghindari dan menjauhkan anak dari proses peradilan sehingga dapat menghindari stigmatisasi terhadap anak yang berhadapan dengan hukum dan diharapkan anak dapat kembali ke dalam lingkungan sosial secara wajar.

Pentingnya proses diversi disadari oleh pembuat kebijakan undangundang, dalam Pasal 6 Undang-Undang Sistem Peradilan Pidana Anak disebutkan bahwa tujuan dari diversi adalah untuk mencapai perdamaian antara korban dan anak, menyelesaikan perkara anak di luar proses peradilan, menghindarkan anak dari perampasan kemerdekaan, mendorong masyarakat untuk berpartisipasi dan menanamkan rasa tanggung jawab kepada anak. Dengan demikian, dapat terlihat UU SPPA memuat klausula yang mendorong anak-anak tidak perlu menjalani proses pidana dengan tanpa menihilkan penanaman rasa tanggung jawab anak dalam proses diversi.

\section{Persepsi dan Faktor Penyebab Kejahatan dalam Lingkungan Anak}

Sebagian besar masyarakat kita belum mengetahui tentang konsekuensi hukum (sanksi) apabila anak melakukan tindakan pidana atau kejahatan. Ada yang menganggap anak belum berhak mendapatakan hukuman apapun itu resikonya, ada juga yang mempunyai persepsi harus mempertanggungjawabkan segala bentuk tindakannya. Hal ini tentu menjadi pandangan yang menarik dikalangan masyarakat, yang mana notabenenya sebagain besar masyarakat masih buta tentang pengetahuan hukum. Berbagai pandangan inilah yang akan menyadarkan kita sebagai orang yang melek hukum untuk memberikan edukasi terkait 
permasalahan hukum, terutama dalam hal ini adalah berorientasi anak yang melakukan tindakan pidana berupa kejahatan.

Anak dalam pandangan orang tua dan keluarga adalah harapan besar dan kebanggaan tersendiri serta menjadi sosok generasi penerus bangsa ini, siapa lagi kalau bukan anka-anak sebagai modal generasi bangsa ini. Dalam pandangan agama anak merupakan karunia yang patut disyukuri sebagai rizki yang diberikan oleh sang Khalik. Dan anak adalah bagian yang tidak dapat terpisahkan dari keberlangsungan hidup manusia dan kelangsungan sebuah bangsa dan Negara.

Perkembangan masyarakat bangsa Indonesia yang berawal dari kehidupan agraris berubah menuju masyarakat industri disertai berbagai gejala lingkungan sosial, pengaruh globalisasi yang demikian besar tampak memiliki kaitan korelasional mupun secara regresional terhadap timbulnya gelaja perilaku delikuensi anak.

Indonesia sebagai negara hukum (rechstaat) yang tertuang dalam konstitusi negara Pasal 1 Ayat (3) UUD 1945², ini memberikan dasar hukum yang kuat terhadap keberlakuan aturan hukum yang jelas disetiap elemen kehidupan masyarakat. Terutama masalah yang terkait dengan anak, sebagai orientasi berfikir kita adalah yang melakukan tidank pidana atau melawan hukum.

Dalam konstitusi bangsa Indonesia, anak memilki peran strategis yang secara tegas dinyatakan bahwasnya negara memberikan jaminan terhadap setiap hak-hak anak atas keberlangsungan hidpnya, tumbuh dan berkembang atas perlindungan dari kekerasan dan tindakan diskriminasi. Dengan demikian jelas, konsekwensi dari ketentuan pasal 28B UUD 1945 mendapatkan sebuah apresiasi yang perlu ditindak lanjuti dengan menbuat sebuah kebijakan pemerintah yang bertujuan melindungi anak yang terlibat dalam berbagai kasus hukum.

Pengertian tentang kenakalan anak atau yang disebut dengan istialah Juvenile Deliquency yang mana secara etimologi dapat diuraiakan, Juvenile yang artinya Young, anak-anak, anak muda, ciri karakteristik pada masa muda sifat-sifat khas pada periode remaja. Kemudian Deliquency yang artinya Doing Wrong, terabaikan/mengabaikan, yang kemudian diperluas artiya menjadi jahat, a-social,

\footnotetext{
${ }^{2}$ UUD 1945, Pasal 1 ayat (3) yang berbunyi: Negara Indonesia adalah Negara hukum
} 
criminal, pelanggar aturan "pembuat rebut, pengacau, penteror", dan lain-lain ${ }^{3}$. Dapat juga Juvenile Deliquency secara etimologi diartikan sebagai kejahatan anak, dan studinya dilihat dari pelakunnya maka Jevenile Deliquency dapat mempunyai arti penjahat anak atau anak jahat.

Konsep sistem peradilan anak merupakan keseluruhan proses penyelesaian perkara anak yang berhadapan hukum, melalui tahap penyelidikan sampai dengan tahap pembimbingan setelah menjalani pidana. ${ }^{4}$

Sedangkan pengadilan anak dalam hukum UU SPPA adalah anak yang telah berumur 12 tahun, tetapi belum berumur 18 tahun. ${ }^{5}$ Kemudian oleh PBB dalam Convention on the Right of the Child (CRC) atau Konversi Hak Anak (KHA) memberikan definisi tentang anak yaitu, anak berarti setiap manusia di bawah umur 18 tahun, kecuali menurut UU yang berlaku pada anak, kedewasaan dicapai lebih awal.

Kemudian dengan keberlangsungan anak yang paling penting adalah mengetahui berbagai faktor-faktor peenting yang menjadi penyebab kenakalan/kejahatan pada anak. Menurut Ramli Atmasasmita, ${ }^{6}$ sebab-sebab timbulnya kenakalan atau kejahatan pada anak, yakni terdapat 2 faktor, faktor motivasi intrinsik dan faktor motivasi ekstrinsik dari kenakalan anak. ;berikut adalah yang termasuk:

Motivasi intrinsik yaitu:

a. Faktor inteligensi: Yakni berkaitan dengan kecerdasan seseorang untuk membuat pertimbangan dan memberikan keputusan. Anak-anak perilaku kejahatan ini pada umumnya inteligensi verbal lebih rendah dan ketinggalan dalam penyampaian hasil-hasil prestasi di sekolah rendah satu wawasan sosial yang kurang tajam, mereka mudah sekali terseret dalam lingkaran kejahatan

b. Faktor usia: Oleh Stephen Hunxitz, mengungkapkan "age is important in the caution of crime (usia adalah faktor yang paling penting dalam sebab timbulnya kejahatan). Diungkap dalam peradilan bahwa pelaku kejahatan

\footnotetext{
${ }^{3}$ Wigiati Soetodjo, Hukum Pidana Anak. Aditama, Jakarta, 2008.

${ }^{4}$ Dalam pengertian UU SPPA Pasal 1 Ayat (1)

${ }^{5}$ Pasal 1 Ayat (3) UU SPPA No. 11 Tahun 2012.

${ }^{6}$ Ramli Atma sasmita, Problem Kenakalan Anak-Anak Remaja, Armico, Bandung, 1983, h. 46.
} 
anak yang paling banyak adalah yang berusia $16 \mathrm{~s} / \mathrm{d} 18$ tahun, dengan perbandingan jumlah 116 dari 134 narapidana anak-anak. ${ }^{7}$

c. Faktor kelamin: disini anak laki-laki cenderung melakukan kejahatan seperti pencurian, penganiayaan, perkosaan, dan sebagainya. Sedangkan anak perempuan lebih sering dalam hal pelanggaran ketertiban umum. Walaupun tidak dipungkiri angka kejahatan anak laki-laki presentasenya lebih tinggi.

d. Faktor Kedudukan Anak dalam Keluarga, adalah kedudukan anak dalam keluarga menurut urutan kelahirannya. Dari hasil penyelidikan terhadap delinquenci dan kriminalitas di Indonesia bahwa kebanyakan dilakukan oleh anak pertama dan anak tunggal atau oleh wanita dan dia satu-satunya diantara selain saudara-saudaranya.

Kemudian faktor ekstrinsik adalah:

a. Faktor keluarga, broken home dan keadaan keluarga yang kurang menguntungkan. Keadaan keluarga yang tidak normal bukan hanya terjadi kekacauan yang berdampak pada anak. Broken home menjadi sumber pemicu yang sangat kuat bagaimana hal ini mendorong bagi anak kurang mendapat perhatian dari orang tua yang menjadi hilangnya perhatian pendidik anak. Serta dalam situasi keluarga yang sibuk, anak dapat mengalami frustasi, konflik-konflik psikologis, hingga keadaan ini dapat dengan mudah mendorong anak terjun dalam dunia hitam.

b. Faktor pendidikan dan sekolah, sekolah menjadi ajang pendidikan kedua setelah keluarga. Maka sekolah ikut bertanggung jawab atas pendidikan anakanak, baik pendidikan keilmuan maupun pendidikan budi pekerti atau tingkah laku. Bahkan banyak atau bertambahnya kenakalan anak secara tidak langsung menunjukkan tentang buruknya sistem pendidikan. Proses pendidikan yang tidak bermutu akan berdampak kurang menguntungkan bagi perkembangan pendidikan anak, bahkan kerap kali menjadi penyebab timbulnya kenakalan anak.

c. Faktor pergaulan anak. Lingkungan pergaulan memberi pengaruh sangat besar terhadap kenakalan anak, situasi sosial yang semakin longgar dan bebas memberikan pengaruh terhadap perkembangan anak. Semakin luar pergaulan

\footnotetext{
${ }^{7}$ Wagiati Soetdjo, Hukum Pidana Anak, Refika Aditama, Bandung, h. 18.
} 
anak tanpa kontrol baik tanpa diimbangi batas-batasan aturan disiplin yang baik akan lebih mudah berhadapan dengan dunia kriminalitas anak.

d. Pengaruh Mass Media. Media mempunyai peran penting terhadap perkembangan pengetahuan dan informasi, keinginan atau kehendak berbuat jahat terkadang timbul karena pengaruh bacaan, informasi, gambar-gambar dan film. Tidak bisa dipungkiri dunia informatika yang berkembang pesat dengan mudahnya mengakses film-film porno, film yang beradegan kekerasan, kejahatan mudah sekali meracuni perkembangan jiwa psikologi anak.

Selain faktor di atas, masih banyak kemungkinan faktor-faktor lain yang kuat berdampak terhadap kenakalan anak, seperti halnya, ekonomi keluarga yang morat-marit (miskin), peredaran minuman keras yang bebas, pengangguran, moralitas masyarakat yang bobrok, dan salah pergaulan juga menjadi pemicu terhadap besar kecil angka kenakalan anak.

\section{Formulasi/Model Sistem Pemidanaan Anak di Indonesia}

Para sarjana memberikan definisi tentang sistem dengan pengertian yang bervariasi, akan tetapi pada dasarnya mempunyai makna yang saling mengisi dan melengkapi. Menurut pandangan RL Ackoff, menyatakan bahwa sistem didefinisikan sebagai entity, conceptual or phycal, which consist of interdependent parts. Sedang menurut Ludwiq Von Bartalanfy mendefinisikan sistem sebagai $a$ complex of elements in mutual interaction ${ }^{8}$. Lebih lanjut oleh Sunaryati Hartono yang mengutip dari pandangan Vissert Hooft mendefinisikan sistem adalah sesuatu yang terdiri dari sejumlah unsur atau komponen yang saling mempengruhi dan terkait satu sama lainnya oleh satu atau beberapa asas ${ }^{9}$. Kemudian oleh prof. Sajtipto Raharjdo mendefinisikan sistem sebagai satu kesatuan yang bersifat komplek, yang terdiri dari bagian-bagian yang berhubungan satu sama lain ${ }^{10}$.

\footnotetext{
${ }^{8}$ Lili Rasyid, IB Wysa Putra, Hukum Sebagai Suatu Sistem, PT Remaja Rosdakarya, Bandung, 1993, h. 42. Mengutip pendapat DC Phillip, 1988, Holistic Thougt in Social Scien, Standford University Press. California, Hlm. 60

${ }^{9}$ Sunaryati Hartono, Politik Hukum Menuju Hukum Nasional, Alumni, Bandung, 1991, h. 56.

${ }^{10}$ Sajtipto Raharjo, Ilmu Hukum, Alumni, Bandung, 1986, h. 88.
} 
Filosofi pemidanaan dalam KUHP dilandasi oleh dasar pemikiran pembalasan atas perbuatan yang telah dilakukan pelaku. Hukuman dianggap suatu hal yang wajar dan rasional kepada setiap orang sebagai akibat telah melakukan tindak kejahatan. Hal ini nampak berbeda dengan pandangan filosofi yang terdapat dalam Konsep KUHP, yang tidak semata-mata ditujuakan pada memberlakukan pelaku pelanggaran, namun berorientasi pula pada pemikiran sejauh maman pemidanaan dapat memberikan perlindungan, baik pelaku maupun korban. Karena itu, pemidanaan yang dijatuhkan dapat menciptakan perlindungan serta kesejahteraan bagi masyarakat. Konsep pemidanaan demikian berpijak dari filosofi pemidanaan yang berdasarkan falsafah restoratif. ${ }^{11}$

Hal terpenting yang melatarbelakngi sistem peradilan anak adalah lahirnya sebuah rancangan sistem peradilan anak (RUU Peradilan Anak) yang telah disampaikan pemerintah kepada DPR dengan Amanat Presiden tanggal 10 November 1995 Nomer R. 12/PU/XII/1995 disusul dengan keterangan pemerintah pada tanggal 1 Maret 1996 dan Jawaban Pemerintah tanggal 18 Maret 1996. Pada saat itu, RUU tentang peradilan anak sedang dalam pembahasana Tingkat III Panitia Khusus (Pansus), yang diikuti Panitia Kerja (Panja), Tim Kecil (Timcil), dan Tim Perumus (Timus). Dalam Pansus ini dibicarakan sekitar 200 Daftar Inventarisasi Masalah (DIM) dari keseluruhan DIM yang sebanyak $294 .{ }^{12}$ Hal demikian adalah sebagai bentuk konsekuensi negara meratifikasi Konvensi HakHak Anak.

Satu hal yang menggembirakan dan patut mendapatkan apresiasi adalah luasnya partisipasi masyarakat dalam menanggapi RUU tentang Peradilan Anak. Demikian Undang-Undang lainnya, partisipasi masyarakat dalam proses pembentukan undang-undang atau peraturan perundang-undangan pada umumnya sangat penting dan sangat diperlukan, hal ini sebagai bentuk dan wujud respon masyarakat yang begitu antusias. Setiap peraturan perundang-undangan pada ujungya akan mengenai rakyat. Karena itu, sangat wajar apabilah rakyat

11 Penyelesaian perkara tindak pidana dengan melibatkan pelaku, korban, keluarga pelaku/korban, dan pihak lain yang terkait untuk bersama-sama mencari penyelesaian yang adil dengan menekankan pemulihan kembali pada keadaan semula, dan bukan pembalasan. (Pasal 1 Ayat (6); sebagai keadilan restroratif/Restrorative Justice).

${ }^{12}$ Ramli Atmasasmita, Peradilan Anak Di Indonesia, Mandar Maju, Bandung, 1997, h. 2. Sebagai Tim Pansus RUU Peradialan Anak. 
senantiasa diberi dan memperoleh kesempatan utuk mengetahui dan menelaahnya. Dengan kesempatan tersebut, diharapkan terbentuk suatu kebijakan perundangundangan yang bermutu memenuhi segala syarat, baik yuridis, filosofis, maupun sosiologis.

Dengan lahirnya UU No. 3 tahun 1997 Tentang Pengadilan Anak menjadi babak baru adanya lex specialis yang mana keberadaaan atau lahirnya suatu undang-undang tersebut mengesampingkan KUHP (Pasal 45, 46, dan 47) yang selama ini dipakai (sebagai lex generalisnya). Akan tetapi, dengan perkembangan waktu dan zaman yang telah berubah dengan cepat menjadikan undang-undang tentang pengadilan anak menghendaki perubahan menuju kesempurnaan suatu peraturan perundang-undangan, yakni dengan lahirnya UU No. 11 Tahun 2012 Tentang Sistem Peradilan Pidana Anak, dan diharapkan dengan digantinya undang-undang berkontribusi lebih relevan mengahadapi berbagai kebutuhan dan tututan perkembangan hukum, khusus dalam menangani permasalahan tindak kejahatan yang dilakukan anak.

Diundangkannya Undang-Undang No. 11 Tahun 2012 Tentang Sistem Peradilan Pidana Anak merupakan langkah yang sangat berarti dalam kehidupan hukum pidana di Indonesia, karena dengan undang-undang tersebut perlindungan hukum terhadap anak memiliki dasar yuridis yang kuat. Salah satu bentuk perlindungan hukum pidana terhadap anak dimaksud adalah diperkenalkannya batas minimal usia anak dan lebih menitikberatkan tindakan bukan pidana atau bahkan mungkin suatu tawaran gagasan radikal peradilan anak tanpa pemidanaan (falsafah/semangat restoratif/) ${ }^{13}$. Baik Undang-Undang No. 3 Tahun 1997 Tentang Pengadilan Anak ataupun Undang-Undang No. 11 Tahun 2012 Tentang Sistem Peradilan Pidana Anak telah mencerminkan prinsip-prinsip penjatuhan pidana sebagaimana diatur dalam dokumen-dokumen internasional. Kondisi ini merupakan hal yang wajar mengingat undang-undang tersebut muncul belakangan

${ }^{13}$ Semangat penerapan UU SPPA Pasal 1 Ayat (6 dan 7) dengan dimaknai dalam nerapakan penjatuhan saksi pada anak dengan model upaya penyelesaian terbaik untuk anak, dengan berbagai pertimbangan perkembangan, psikologi, usia, mental, dan kemampuan bertanggung jawab anak mendapat perhatian perlakuan yang khusus disbanding peneranapan sanksi pada pelaku yang melibatakan orang dewasa. 
setelah dokumen internasional, ${ }^{14}$ yang mengatur masalah perlindungan hukum terhadap anak.

Ketentuan mengenai penjatuhan pidana atau tindakan dalam undangundang anak telah merespon sejumlah prindip-prinsip perlindungan anak dalam berbagai dokumen internasional bermuara pada pengakuan dan jaminan pertumbuhan dan perkembangan anak baik secara fisik, mental, dan sosial. Ini berarti ketentuan tersebut memiliki relevansi terhadap tujuan sistem peradilan pidana berupa resosialisasi pelaku tindak pidana, pencegahan masyarakat, dan kesejahteraan masyarakat. Dengan kemungkinan-kemungkinan ini, hakim diberi kesempatan untuk mempertimbangkan dan menentukan pidana yang tepat dijatuhkan pada si anak. Beberapa perubahan dan perkembangan, khususnya dalam Undang-Undang No. 11 Tahun 2012 Tentang Sistem Peradilan Pidana Anak yang baru disahkan oleh Presiden bersama DPR pada akhir bulan Juli 2012 lalu lebih baik dibanding dengan undang-undang No. 3 Tahun 1997 Tentang Pengadilan Anak. Tujuannya adalah untuk semakin efektifnya perlindungan anak dalam sistem peradilan demi terwujudnya Sistem Peradilan Pidana yang Terpadu ("integrated criminal justice system") atau juga bisa jadi pemunduran terhadap nilai-nilai yang telah ada sebelumnya.

Sebuah upaya yang patut diapresiasi bahwa pemerintah telah mengadakan reformasi hukum dibidang pembaruan undang-undang atau substansi hukum (legal substance reform), tetapi juga yang lebih diharapkan lagi adalah terciptanya pembaruan struktur hukum (legal structure reform) dan pembaruan budaya hukum (legal culture reform) yang termasuk di dalamnya juga pembaharuan etika hukum dan ilmu/pendidikan hukum (legal ethic and legal science/education reform ${ }^{15}$.

Pemikiran kepentingan tentang anak pertama kali dikumandangkan oleh penulis ternama asal Swedia, Ellen Key dalam karyanya Century Of the Child (1909), yang merupakan buku terlaris pada waktu itu tentang upaya perhatian kapasitas anak selaku insan manusia (Human Being) tidak semestinya tumbuh

\footnotetext{
${ }^{14}$ Yaitu KHA (Konvensi Hak Anak/convention on the right of the child) sebagai Negara yang ikut meratifikasi wajib menerapkan kaidah hokum dalam dokumen konvensi dengan melakukan harmonisasi hokum.

${ }^{15}$ Barda Nawawi Arif, Restrukturisasi/Rekontruksi Sistem Hukum Pidana Indonesia, Pustaka Magister, 2008, h. 1.
} 
sendiri dibiarkan tanpa perlindungan. ${ }^{16}$ Dengan demikian, Sejatinya anak membutuhkan pihak-pihak tertentu, baik orang tua/keluarga, masyarakat, pemerintah, dan negara selaku pembuat regulasi (regulator body), semuanya mendukung tumbuh berkembang anak secara wajar guna menjaga jangan sampai mereka mengalami problem hukum pada masa mendatang.

Sistem pemidanaan merupakan suatu sistem keterpaduan dalam masyarakat yang mempunyai tujuan untuk menanggulangi masalah kejahatan dalam arti mengendalikan kejahatan agar berada dalam batas-batas toleransi masyarakat. Dalam konteks sistem peradilan pidana anak, Sudarto mengemukakan, bahwa didalam peradilan pidana anak terdapat aktivitas pemeriksaan dan pemutusan perkara yang menyangkut kepentingan anak, yaitu segala aktivitas yang dilakukan oleh polisi, jaksa, hakim, dan pejabat lain, harus berdasarkan suatu prinsip ialah demi kesejahteraan dan kepentingan anak, ${ }^{17}$ dengan kata lain penerapannya dari proses awal sampai akhir berbeda dengan pelaku orang dewasa pada umumunya. Bahwasanya pengertian mengenai kebijakan merupakan sebagai serangkaian tindakan/kegiatan yang ditetapkan oleh pemerintah yang mempunyai tujuan atau orientasi pada tujuan tertentu demi kepentingan seluruh masyarakat. ${ }^{18}$ Sistem pemidanaan secara subtansial merupakan keseluruhan sistem norma hukum pidana materiil yaitu untuk penjatuhan dan pelaksanaan pidana. Oleh karena itu, keseluruhan peraturan perundang-undangan baik yang ada dalam KUHP maupun diluar KUHP pada hakikatnya merupakan satu kesatuan sistem pemidanaan sebagai aturan umum dan aturan khusus ${ }^{19}$.

Sistem peradilan pidana anak menurut Undang-Undang No. 11 tahun 2012 Tentang Sistem Peradilan Pidana Anak Pasal 1 angka (1) adalah keseluruhan proses penyelesaian perkara anak berhadapan dengan hukum, mulai tahap penyelidikan dengan tahap pembimbingan setelah menjalani pidana. Sistem

\footnotetext{
${ }^{16}$ Ellen Key, Century Of the Child, (London: Calouste Gulbekian Foundation), 1909, h. 1.

${ }^{17}$ Sudartao, Kapita Selekta Hukum Pidana, Alumni, Bandung, 1981, h, 129.

${ }_{18}$ M. Irfan Islamy, Prinsip-Prinsip Perumusan Kebijakan Negara. Bina Aksara, Jakarta, 1988, h. 20.

${ }^{19}$ Barda Nawawi A, Perkembangan Sistem Pemidanaan Di Indonesia, Pustaka Magister, Semarang, 2007, h. 10.
} 
peradilan pidana anak berbeda dengan sistem peradilan orang dewasa dalam berbagai segi. Peradilan pidana anak dalam segala aktivitas pemeriksaan dan pemutusan perkara yang lebih menekankan atau memusatkan kepentingan anak harus menjadi pusat perhatian dalam peradilan pidana anak. ${ }^{20}$ Salah satu ciri yang melekat pada sistem peradilan pidana anak adalah para pemangku hukum dapat mengakhiri proses peradilan pada setiap saat, sejak keadaan diketahui oleh yang berwenang menghentikannya. ${ }^{21}$

KUHP mengatur sistem pemidanaan terhadap anak, meliputi batas usia di bawah 16 tahun (minderjarig) sebagai orang yang dikategorikan anak sebagai pelaku tindak pidana, tanpa memberikan batas usia tertentu sehingga seolah-olah anak yang baru lahirpun dapat dimintai pertanggungjawaban pidana. Sedangkan masalah jenis sanksi yang diancamkan terhadap anak, selain mengatur ancaman sanksi pidana sebagaimana ditegaskan dalam Pasal 45,46, dan 47 KUHP (ketika masih berlaku) yang berupa pidana pokok dan pidana tambahan. KUHP mengatur pula jenis sanksi yang berupa tindakan, yeng meliputi; mengembalikan kepada orang tua/wali, dididik oleh negara tanpa pidana apapun, diserahkan kepada seseorang atau badan hukum, yayasan ataupun lembaga amal yang menyelenggarakan pendidikan (Pasal 45 dan 46 KUHP). Dengan demikian ancaman terhadap anak menganut sistem dua jalur atau "Double Track System". Dilihat dari latar belakang kemunculan ide tersebut, dapat disimpulkan bahwa sistem tersebut adalah kesetaraan antara sanksi pidana dan sanksi tindakan. Ide kesetaraan ini dapat ditelusuri lewat perkembangan yang terjadi dalam sistem sanksi hukum pidana dari aliran klasik kealiran modern dan aliran neo-klasik. ${ }^{22}$ Dengan hadirnya undang-undang sistem peradilan pidana anak ini merupakan hal yang baru, yaitu mengenai ditambahnya batas usia pertanggungjawaban anak menjadi $12 \mathrm{~s} / \mathrm{d} 14$ tahun untuk dikenai tindakan dan $14 \mathrm{~s} / \mathrm{d} 18$ tahun untuk tindak pidana penjara. Sebagaimana yang terdapat dalam pasal 69 (2) yang menyiratkan

${ }^{20}$ Maidin Gullom, Perlindungan Hukum terhadap Anak dalam Sistem Peradilan Anak di Indonesia, Refika Aditama, Jakarta, 2009, h. 6.

21 Abintoro Prakoso, Pembaruan Sistem Peradialan Pidana Anak, Lakbang, Jakarta, 2012, h. 201.

22 Sholehuddin. System sanksi dalam hukum pidana, ide dasar double track system \& implementasinya. Rajawali press, Jakarta. 2004, h. 24. 
bahwa anak yang belum berusia 14 tahun "hanya" dapat dikenai tindakan dan hal ini harus kita pahami secara komprehensif serta mendalam mengenai sistem penerapan batas usia anak dalam lex spesialisis saat ini. ${ }^{23}$

Riset psikologi juga mengamini fakta tersebut. Karena anak yang dalam tahap perkembangan menuju remaja hingga dewasa. Diyakini masih dalam tahap/stadium pencarian indentitas, pencarian jati diri. Bidang kajian psikologi remaja menyatakan anak yang melakukan kejahatan. Boleh jadi karena kondisi yang diakibatkan apa yang dinamakan "krisis identitas." Maka muncul kemudian istilah anak nakal (Juvenile Delinquent). ${ }^{24}$

Dalam penegakan hukum terhadap anak yang melakukan kejahatan. Berbeda perlakuannya dengan orang dewasa, yang melakukan tindak pidana. Semuanya jelas dilandaskan pada asas kepentingan terbaik anak (the best interest of the child). Sebagaimana yang diamanatkan dalam konvensi internasional tentang hak-hak anak. Berangkat dari asas tersebut, maka posisi anak oleh undang-undang sistem peradilan pidana anak, memberikan petunjuk dalam hal penentuan pidana pokok seorang anak yang melakukan tindak pidana. Semisal pidana penjara yang dapat dijatuhkan kepada anak paling lama 1/2 (satu perdua) dari maksimum ancaman pidana penjara bagi orang dewasa. ${ }^{25}$ Kemudian yang menarik mengenai penjatuhan hukuman dimana merupakan tindak pidana yang diancam dengan ancaman pidana mati atau pidana seumur hidup, maka penjatuhan pidana anak adalah pidana penjara paling lama adalah 10 tahun, sebagai batasan ancaman maksimum penjara khusus untuk anak. ${ }^{26}$ Bahkan dalam proses penyidikan, penangkapan, penahanan, pemeriksaan di pengadilan hingga dalam lembaga pemasyarakatan. Hak-hak anak lebih diutamakan sebagai realisasi pengutamaan kepentingan terbaik anak. Suatu hal yang patut dan memang sangat

\footnotetext{
${ }^{23}$ Barda Nawawi A, Tujuan dan Pedoman Pemidanaan, Undip Pers, Semarang, 2009, h. 131.

${ }^{24}$ Siti rahayu dan Jonh Monsk dalam Psikologi Perkembangan Anak, Gajah Mada Press. Hal 72 .

${ }^{25}$ UU No. 11 Tahun 2012 Tentang Sistem Peradilan Anak, Pasal 81 (2): Pidana penjara yang dapat dijatuhkan kepada Anak paling lama 1/2 (satu perdua) dari maksimum ancaman pidana penjara bagi orang dewasa.

${ }^{26}$ Ibid, Pasal 81 Ayat (6): Jika tindak pidana yang dilakukan Anak merupakan tindak pidana yang diancam dengan pidana mati atau pidana penjara seumur hidup, pidana yang dijatuhkan adalah pidana penjara paling lama 10 (sepuluh) tahun.
} 
layak jika dalam undang-undang sistem peradilan pidana anak menerapkan keadilan restoratif. Karena anak tidaklah secara sepenuhnya dikendalikan oleh adanya dorongan dalam dirinya sehingga mewujudkan tindak pidana/melawan hukum.

Kebijikan-kebijakan baru, seperti ide restoratif juga senada dengan ide-ide dalam mediasi penal (penal mediation), hal demikian karena prinsip kerja restoratif hakikatnya sama dengan prinsip kerja mediasi penal, fakta-fakta demikian ini merupakan salah satu bentuk bentuk model-model dari mediasi penal yang salah satu adalah model alternative penyelesaian sengketa/kasus diluar pengadilan atau "Alternative Dispute Resolution (ADR)". 27 Dengan model "Family And Community Group conferences" model ini telah dikembang di berbagai Negara seperti di Australia dan New Zealand, pada dasarnya tidak hanya melibatkan korban dan pelaku tindak pidana, tetapi keluarga dan partisipasi masyarakat lainnya, pejabat tertentu polisi dan hakim anak. Berangkat dari sebuah usaha inilah diharapkan mengahasilkan sebuah kesepakatan yang komprehensip dan memuaskan korban serta dapat membantu untuk menjaga si pelaku dari kesusahan atau persoalan berikutnya. Walaupun pada umumnya penyelesaian mediasi penal tidak dikenal dalam hukum pidana dan cenderung pada kasus-kasus perdata, namun dalam praktiknya kasus-kasus pidana sering diselesaikan di luar pengadilan melalui berbagai diskresi aparat penegak hukum atau melalui mekanisme musyawarah/perdamaian dengan perantara lembaga masyarakat, tokoh, ulama, advokat, dan para legal yang ada. Salah satu hal terpenting adalah masuknya kewajiban untuk menyediakan bantuan hukum bagi anak-anak yang berhadapan dengan hukum. Selain itu, proses penyelesaian perkara-perkara anak di luar sistem peradilan pidana juga mulai diakui secara resmi sebagai bagian dari mekanisme keadilan restoratif. Meski demikian, UU SPPA tentu memiliki sejumlah kelemahan mendasar yang patut disesalkan.

Dalam praktiknya pemidanaan/penjara hanya digunakan sebagai upaya terakhir (last resort), terutama anak bermasalah dengan hukum yang batas usianya diatas 14 sampai dengan kurang 18 tahun. Hal ini, juga didasarkan berbagai dokumen internasional antara lain Artikel 37 Konvensi Hak-Hak Anak atau

\footnotetext{
${ }^{27}$ Barda Nawawi Arif, Mediasi Penal, Pustaka Magister, Semarang, 2012, h. 10.
} 
Resolusi PBB 44/25 dan Rule 19.1 SMR-JJ atau Beijing Rule (Standar usia minimum anak). Adapun kategori hukuman pidana pokok anak yang sesuai kebijakan UU SPPA diantara berupa pidana peringatan, pidana dengan syarat, pelatihan kerja, pembinaan dalam lembaga, dan penjara. Sedangkan sanksi tindakan di antaranya pengembalian pada orang tua/wali, penyerahan kepada seseorang, pencabutan SIM, perawatan di LPKS, perawatan di rumah sakit jiwa, kewajiban mengikuti pendidikan formal/pelatihan-pelatihan yang diadakan oleh pemerintah. Namun, sanksi pidana dan tindakan di atas ini merupakan sebuah pedoman terhadap penjatuhan sanksi bagi anak ketika bermasalah dengan hukum.

Hal menarik perhatian dalam dunia hukum anak ini juga nampak ketika suasana beracara sidang pengadilan anak, dimana hakim atau penuntut yang jauh terkesan formal seperti tidak memakai jas/jubah atau atribut berbau pengadilan. Selain memprioritaskan penyidik, penuntut, hakim yang mempunyai criteria dan dedikasi terhadap anak. Hal ini, tentu bukan dengan tujuan yang jelas akan tetapi upaya ketakutan psikis dalam jiwa anak, gambaran-gambaran kekhususan dalam sistem pemidanaan merupakan sebagai suatu bentuk formulasi/model/payung hukum anak yang selama ini tidak diketahui awam hukum.

\section{Diversi Sebagai Salah Satu Model Upaya Hukum Bagi Anak}

Diversi merupakan suatu bentuk pengalihan penyelesaian perkara Anak dari proses peradilan pidana ke proses di luar peradilan pidana. Diversi bagi tidak pelaku anak adalah untuk menyediakan alternatif yang lebih baik dibanding dengan prosedur resmi beracara di pengadilan. Program diversi sangat member keuntungan dalam penanganan awal dan cepat terhadap perilaku menyimpang yang mengubah cara pandang terhadap sistem yang selama hukum positif yang selama ini ada. ${ }^{28}$ Bahwa mestinya proses diversi mengutamakan kepentingan terbaik bagi anak, bukan hanya pengesampingan/perdamaian antara korban dengan anak. Selain itu proses diversi semestinya tidak terkungkung dengan batasan ancaman penjara dibawah 7 tahun. Pada prinsipnya sesuai dengan prinsipprinsip hukum internasional, proses diversi haruslah mengutamakan kepentingan

28 Setyo Wahyudi, Diversi Dalam Sistem Peradilan Anak Di Indonesia, Undip Pers, Semarang, 2009, h. 57. 
terbaik bagi anak. Walaupun demikian, UU SPPA membuka kemungkinan proses diversi terhadap tindak pidana yang dilakukan anak tanpa harus ada kesepakatan diversi apabila tindak pidana tersebut bersifat pelanggaran, bagian dari tindak pidana ringan, tindak pidana tanpa korban atau nilai kerugian korban tidak lebih dari nilai upah minimum provinsi setempat.

Hal lain yang patut populerkan adalah munculnya upaya hukum, yang berupa diversi. Dalam UU SPPA ini, diversi menjadi sesuatu yang wajib dilakukan pada penyidikan, penuntutan, dan hakim di pengadilan. Dalam kaca mata hukum model ini yang sangat baik untuk mendapatkan respon, karena sebagai pilihan alternatif dalam menghadapi kebuntuan hukum oleh para pejabat penegak hukum dari level kepolisian hingga ke pengadilan negeri. Namun memperkenalkan implementasi baru juga bukan merupakan sesuatu yang mudah tanpa mempunyai pendekatan keilmuan yang cukup luas. Adapun substansi yang diatur dalam undang-undang ini, antara lain, mengenai penempatan anak yang menjalani proses peradilan dapat ditempatkan di Lembaga Pembinaan Khusus Anak (LPKA). Substansi yang paling mendasar dalam Undang-Undang ini adalah pengaturan secara tegas mengenai Keadilan Restoratif dan Diversi yang dimaksudkan untuk menghindari dan menjauhkan anak dari proses peradilan sehingga dapat menghindari stigmatisasi terhadap anak yang berhadapan dengan hukum dan diharapkan anak dapat kembali ke dalam lingkungan sosial secara wajar. Oleh karena itu, sangat diperlukan peran serta semua pihak dalam rangka mewujudkan hal tersebut. Proses itu harus bertujuan pada terciptanya keadilan restoratif, baik bagi anak maupun bagi korban. "Keadilan restorative” merupakan suatu proses implemntasi dari diversi, yaitu semua pihak yang terlibat dalam suatu tindak pidana tertentu bersama-sama mengatasi masalah serta menciptakan suatu kewajiban untuk membuat segala sesuatunya menjadi lebih baik dengan melibatkan korban, anak, dan masyarakat dalam mencari solusi untuk memperbaiki, rekonsiliasi, dan menenteramkan hati yang tidak berdasarkan pembalasan. $^{29}$

\footnotetext{
${ }^{29}$ Konsep keadilan Restoratif justice dalam UU SPPA No. 11 Tahun 2012, Pasal 1 Ayat (6 dan 7)
} 
UU Sistem Peradilan Pidana Anak merupakan cerminan amanat UUD 45 dan tertuang dalam Konvensi Tentang Hak-Hak Anak Resolusi PBB No. 109 Tahun 1990 yang telah diratifikasi dengan Keputusan Presiden No. 36 Tahun 1990. UU ini disusun dalam rangka mewujudkan tujuan "restorative justice" sebagai salah satu alternatif pelaksanaan pemidanaan bagi anak yang berkonflik dengan hukum. Didalamnya dinyatakan, penangkapan, penahanan, dan penghukuman/pemenjaraan harus menjadi langkah terakhir yang diambil dalam penanganan anak yang berkonflik dengan hukum (ultimum meredium) ${ }^{30}$ dan untuk jangka waktu yang paling pendek/waktu yang sesingkat-singkatnya.

Dalam Beijing Rules tentang administrasi peradilan bagi anak, persetujuan menempuh proses diversi berada pada anak yang berkonflik dengan hukum (pelaku) bukan pada korban. Dalam konteks diversi, korban dapat mengajukan syarat-syarat yang tentunya rasional dan terukur serta mempertimbangkan kepentingan terbaik bagi anak. Bahkan pembunuh sekalipun dimungkinkan dilakukan diversi. Sebagai contoh adalah diversi, meski diversi telah diakui secara resmi sebagai bagian dari mekanisme keadilan restoratif, namun diversi dalam UU SPPA ini sangat mengedepankan faktor perdamaian antara korban tindak pidana dengan anak yang berhadapan dengan hukum. Selain itu proses diversi hanya bisa dilakukan bila tindak pidana tersebut diancam dengan pidana kurang dari 7 tahun penjara dan bukan pengulangan tindak pidana. ${ }^{31}$

Hasil kesepakatan Diversi dapat berbentuk, antara lain:

a. perdamaian dengan atau tanpa ganti kerugian

b. penyerahan kembali kepada orang tua/Wali

c. keikutsertaan dalam pendidikan atau pelatihan di lembaga pendidikan atau LPKS paling lama 3 (tiga) bulan; atau

d. pelayanan masyarakat.

Tetapi aturan di Indonesia masih belum mengikuti Beijing Rules. Sangat sayangkan hasil pembahasan Panitia Kerja RUU SPPA tertanggal 6 Februari 2012

\footnotetext{
${ }^{30}$ Sudarto, 1990, Hukum Pidana, Undip Pres, Semarang, Hlm.

31 Meskipun dlam hal ini, IKaHI masih memperdebatkan atas pemberian diversi/mediasi yang tidak sejalan dengan pandangan keadilan pidana yang bersifat retributive (pembalasan), karena upaya diversi ini pada ujungnya mempunyai niat meniadakan hukuman yang dianggap menyelewengkan nilai-nilai keadilan serta ganjaran yang setimbal bagi pelaku kejahatan.
} 
${ }^{32}$ bahwa keputusan diversi digantungkan kepada persetujuan korban. Artinya jika dalam proses upaya diversi korban tidak menyetujui maka aparat penegak hukum (polisi, jaksa, dan hakim) tidak dapat membuat keputusan diversi. Tentunya hal ini bertentangan dengan peraturan administrasi peradilan bagi anak (Beijing Rules).

\section{PENUTUP}

Kebijakan sistem pemidanaan mencerminkan suatu upaya perlindungan terhadap anak maka perlu sebuah upaya pembinaan terhadap lembaga-lembaga penegak hukum untuk lebih mengedepankan kepentingan anak tanpa mendiskriminasikannya. Namun, dengan terbenamnya ide filosofi yang dalam/kritis serta semuanya demi memberikan upaya perlindungan terhadap anak, maka para penegak hukum harus membekali diri dengan pengetahuan yang lebih luas. Akan tetapi, kesemuanya yang ada dalam sistem tersebut kembali pada profesionlitas individu para aparat penegak hukum yang diharapkan mempunyai dedikasi yang tinggi demi masa depan kepentingan terbaik untuk anak.

Kebijakan sistem pemidanaan dalam upaya perlindungan terhadap anak dimasa yang akan mendatang hendaknnya bisa lagi menyempurnaan produk undang-undang/peraturan yang dalam dalam UU No.11/2012 sekarang ini. Dimana produk suatu uu/sistem harus lebih fleksibel sesuai dengan cepatnya kemajuan perkembangan zaman. Apalagi dengan munculnya isu-isu khususnya terkait dengan batas usia pertanggungjawaban pidana, pedoman pemidanaan, dan jenis-jenis sanksi. Penyempurnaan itu pada hakikatnya tetap mengacu pada konsep KUHP 2012 (walaupun masih dalam tahap rancangan dan pengesahan) yang diharapkan lebih jelas, komprehensip, rinci dalam rumusan pasalnya, serta dengan semangat tetap memperhatikan pertimbangan berbagai dokumen internasional selain itu, KUHP negara-negara asing juga bisa sebagai bahan studi perbandingan dan kelengkapan dalam upaya penyusunan peraturan atau sistem baru yang akan diterapkan nantinya.

Hal-hal yang baru dalam orientasi pelaksanaan sistem pemidanaan anak diantaranya adalah mengenai batas usia anak yang dinaikkan, dari usia 8 tahun

${ }^{32}$ RUU No.11/2012 Tentang Sistem Peradilan Pidana Anak, ketika itu belum disyahkan dan baru tanggal. 30 juli 2012 . 
menjadi 12 tahun sebagai usia yang layak mempertanggungjawabkan perbuatan dan secara psikis mental sudah stabil (sebagai catatan walaupun batas usia disetiap negara berbeda-beda) ${ }^{33}$, lahirnya lembaga-lembaga baru seperti LPAS (lembaga penempatan anak sementara), LPKS (lembaga penyelenggara kesejahteraan sementara), Pekerja Sosial Profesional, kemudian Tenaga Kesejahteraan Sosial, munculnya penerapan diversi secara konkrit dalam pengaturan UU SPPA, serta implementasi dari diversi adalah upaya penyelesaian anak melalui keadilan restoratif. Ini semua adalah sebagai wujud bentuk apresiasi memberikan kepentingan terbaik bagi anak yang bermasalah dengan hukum.

\section{DAFTAR PUSTAKA}

Hadisuprapto, Paulus, Delinkuensi Anak (Pemahaman dan Penanggulangannya). Malang: Bayu Media, 2008.

Maidin Gullom, Perlindungan Hukum terhadap Anak dalam Sistem Peradilan Anak di Indonesia, Refika Aditama, Jakarta, 2009.

Nawawi Arif, Barda, Perbandingan Hukum Pidana,_Rajawali Pers, Jakarta, 2002.

Nawawi Arif, Barda, Perkembangan Sistem Pemidanaan di Indonesia, PT. Pustaka Magister, Semarang, 2008.

Nawawi Arif, Barda, RUU KUHP BARU: Sebuah Restrukturisasi Sistem Hukum Pidana Indonesia, PT. Pustaka Magister, Semarang, 2008.

Nawawi Arif, Barda, Tujuan dan Pedoman Pemidanaan. (perspektif pembaharuan Hukum Pidana \& Perbandingan Beberapa Negara), Undip Press, Semarang, 2009.

Nawawi Arif, Barda, Kebijakan Formulasi: Ketentuan Pidana Dalam Peraturan Perundang-Undangan, PT. Pustaka Magister, Semarang, 2012.

Prakoso, Abintoro, Pembaruan Sistem Peradilan Pidana Anak, Laksbang Grafika, Yogyakarta, 2012.

Raharjo, Soejipto, Pengantar Tata Hukum Indonesia, Rajawali Pers, Jakarta.

Rahayu, Siti dan Monks, John, Psikologi Perkembangan Anak, UGM Pers, Yogyakarta, 1992.

Sambas, Nandang, Pembaruan Sistem Pemidanaan. Graha Ilmu, Jakarta, 2010.

Sudarto, Kapita Selekta Hukum Pidana, Alumni, Bandung, 1981.

Sholahuddin, Sistem Sanksi Dalam Hukum Pidana (Ide Dasar Double Track System dan Implementasinya), Rajawali Press, Jakarta, 2004.

Sudarto, Hukum Pidana I, Yayasan Sudarto, Semarang, 1990.

Wahyudi, Setyo, Diversi dalam Sistem Peradilan Anak, Undip Press, Semarang, 2009.

\section{PERATURAN PERUNDANG-UNDANGAN}

Kitab Undang-Undang Hukum Pidana (KUHP), Jakarta: Bumi Aksara. Muljatno

\footnotetext{
${ }^{33}$ Barda Nawawi A, Perbandingan Hukum Pidana, Rajawali Pers, Jakarta, 2002, h.11.
} 
Kitab Undang-Undang Hukum Acara Pidana (KUHAP), Jakarta: Bumi Aksara. Muljatno

Undang-Undang No. 4 Tahun 1974 Tentang Kesejakteraan Anak

Undang-Undang No. 12 Tahun 1995 Tentang Pemasyarakatan

Undang-Undang No. 3 Tahun 1997 Tentang Pengadilan Anak (Diganti)

Undang-Undang No 39 Tahun 1999 Tentang Hak Asasi Manusia

Undang-Undang No. 26 Tahun 2000 Tentang Pengadialan Ham

Undang-Undang No. 23 Tahun 2002 Tentang Perlindungan Anak (Diganti)

Undang-Undang No. 11 Tahun 2012 Tentang SistemPeradilan Pidana Anak ( UU Terbaru)

Undang-Undang No. 35 Tahun 2014 Tentang Perlindungan Anak (UU Terbaru)

Kepres RI Nomer 87 Tahun 2002 Tentang Rencana Aksi Nasional Penghapusan Eksploitasi Seksual Komersial Anak

Kepres RI Nomer 88 Tahun 2002 Tentang Rencana Aksi Nasional Penghapusan Perdagangan ( Trafficking) Perempuan dan Anak

Kepres RI Nomer 36 Tahun 1990 Tentang Pengesahan Convention On The Rights of The Child ( Konvensi Tentang Hak-hak Anak)/Konvensi-Konvensi PBB Tentang Anak.

\section{INSTRUMEN INTERNASIONAL}

1924 Geneva Declaration of the Rights of the Child

1959 UN General Assembly Declaration on the Rights of the Child

1966 International Convenant on Civil and rights of the Child

1966 International Convenant on Economic, Social, and Cultural Rights

1989 UN Convenan on the Rights of the Child

Tabel usia pertanggung jawaban anak di berbagai negara

\begin{tabular}{|l|c|}
\hline \multicolumn{1}{|c|}{ NAMA NEGARA } & $\begin{array}{c}\text { USIA MINIMAL } \\
\text { PERTANGGUNG JAWABAN } \\
\text { PIDANA }\end{array}$ \\
\hline Australia & 14 Tahun \\
\hline Belgia & 18 Tahun \\
\hline Denmark & 15 Tahun \\
\hline Inggris & 10 Tahun \\
\hline Finlandia & 15 Tahun \\
\hline Perancis & 13 Tahun \\
\hline Jerman & 14 Tahun \\
\hline Yunani & 12 Tahun \\
\hline Irlandia & 7 Tahun \\
\hline Itali & 14 Tahun \\
\hline
\end{tabular}


MIMBAR YUSTITIA Vol. 2 No. 2 Desember 2018

P-ISSN 2580-4561 (Paper) E-ISSN 2580-457X (Online)

\begin{tabular}{|l|c|}
\hline Luxemburg & 18 Tahun \\
\hline Belanda & 12 Tahun \\
\hline Irlandia Utara & 8 Tahun \\
\hline Portugal & 16 Tahun \\
\hline Skotlandia & 8 Tahun \\
\hline Spanyol & 16 Tahun \\
\hline Swedia & 15 Tahun \\
\hline
\end{tabular}

